\title{
FSH-induced phosphoprotein phosphatase 2A-mediated deactivation of particulate phosphodiesterase- 4 activities is abolished after alteration in proteoglycan synthesis in immature rat Sertoli cells
}

\author{
Guénaëlle Levallet, Jérôme Levallet and Pierre-Jacques Bonnamy \\ Laboratoire CEstrogènes et Reproduction, UPRES-EA 2608, INRA USC 2006, Université de Caen, 14032 Caen Cedex, France \\ (Correspondence should be addressed to P-J Bonnamy; Email: pierre-jacques.bonnamy@unicaen.fr)
}

\begin{abstract}
Cessation of rat testicular Sertoli cells proliferation around days 15-20 post partum is associated in vitro with the highest rise in rolipram-sensitive cAMP-catabolizing phosphodiesterase-4 activities (PDE4s) triggered by FSH during the early postnatal period. The transient nature of FSH-induced increase in PDE4s suggests concomitant changes in both PKA-mediated activation and subsequent deactivation of these activities. In this study, we demonstrated that the deactivation of FSH-stimulated particulate, but not soluble, PDE4s in cultured Sertoli cells from 20-dayold rats was inhibited by phosphoprotein phosphatase (PP) inhibitors, okadaic acid, and calyculin A. Moreover, the deactivation of FSH-stimulated particulate PDE4s was timely related with the gonadotropin-induced increase in both particulate PP2A activity and particulate PP2A catalytic subunit immunoreactive expression independently of any transcriptional regulation of that subunit. Both the FSH-induced increase in
\end{abstract}

recruitment/activation of particulate PP2A and the subsequent deactivation of particulate PDE4 were abolished when Sertoli cell proteoglycans (PGs) synthesis was altered by sodium chlorate. Sodium chlorate effect was developmentally regulated as evidenced by its ability to silence particulate PDE4 deactivation only in non-proliferating (from 20- to 30-day-old rats) but not in proliferating (from 10-day-old rats) Sertoli cells. All these data suggested that PGs could be involved in the FSH-induced recruitment/activation of PP2A. Particularly, developmentally regulated transmembrane syndecans, the most abundant PGs in Sertoli cells, by targeting PP2A at the membrane level could allow developmental control of activated particulate PDE4s and, potentially, other signaling phosphoproteins, including the FSH receptor, during the early postnatal period.

Journal of Endocrinology (2008) 197, 45-54

\section{Introduction}

Phosphodiesterases (PDEs) that catalyze hydrolysis of cAMP and cGMP are potent regulators of intracellular concentrations of these second messengers. Among the 11 subfamilies (from PDE1 to PDE11) that differ in terms of substrate, inhibitor specificities, and molecular sequence (Bender \& Beavo 2006, Lugnier 2006, Conti \& Beavo 2007), the cAMP-specific PDE4 subfamily is of primary importance since its members are subject to cAMP feedback regulation mediated through protein kinase A (PKA)-mediated phosphorylation and transcription (Houslay \& Adams 2003). PDE4s are encoded by four genes generating more than 25 spliced variants that have been divided into long, short, and super-short isoforms according to the presence or absence of two conserved $\mathrm{N}$-terminal sequences called upstream conserved region (UCR)-1 and UCR-2, which are thought to play a determinant role in their intracellular targeting (Baillie et al. 2005). In testicular Sertoli cells, PDE4D have been recognized as the main cAMP-catabolizing enzymes (Morena et al. 1995) regulating the response to the gonadotropin follicle-stimulating hormone (FSH) that controls the acquisition of differentiated functions. Although FSH triggers multiple signals in Sertoli cells (Walker \& Cheng 2005), the cAMP pathway constitutes the primary route for FSH action. Increase in cAMP intracellular concentrations is tightly controlled by simultaneous increase in PDE4 activities resulting from PKA-mediated serine phosphorylation of long isoforms and cAMP-mediated transcriptional up-regulation of short isoforms (Richter et al. 2005). In rat Sertoli cells, transition from proliferative to quiescent and differentiated phenotype during the early postnatal period (between 15 and 20 days post partum) is associated with switching of FSH receptor from mitogen activated protein kinase (MAPK) $3 / 1$ activation to adenylate cyclase activation (Crepieux et al. 2001). The turning age of 20 days post partum is also characterized by both the highest cAMP response to FSH and the highest particulate and soluble PDE4s activation by the gonadotropin without changes in subcellular distribution and expression of PDE4D proteins (Levallet et al. 2007b). Thus, the amplification of transient response in both subcellular fractions at day 20 in Sertoli cells 
suggests developmental changes not only in PKA-mediated phosphorylation of long PDE4D isoforms but also in their subsequent deactivation by a putative phosphatase activity.

Very little is known about serine/threonine protein phosphatases involved in the regulation of phosphorylation of PDE4D long isoforms. To date, only deactivation of PDE3B has been shown to involve phosphoprotein phosphatase 2A (PP2A) in rat adipocytes (Resjo et al. 1999). PP2A, a dual serine/threonine and tyrosine phosphatase, through its ability to dephosphorylate number of signaling proteins, is thought to be associated with growth inhibition and cell arrest (Janssens et al. 2005). Most of the cellular PP2A holoenzymes are in trimeric form, in which a $36-\mathrm{kDa}$ catalytic C subunit and a $65-\mathrm{kDa}$ regulatory $\mathrm{A}$ subunit are associated with a particular regulatory B subunit (Janssens \& Goris 2001). The nature of PP2A-B subunit determine both substrate specificity and subcellular localization of the holoenzyme (Janssens \& Goris 2001, Strack et al. 2004, Janssens et al. 2005) through the formation of signaling complexes in which both protein kinase and phosphatase are often associated (Millward et al. 1999, Wong \& Scott 2004). Cell proteoglycans (PGs) appear as potential candidates to anchor such signaling enzymes as suggested by the alteration of FSH-induced particulate PDE4 activities triggered by the inhibition of $\mathrm{PG}$ synthesis in rat Sertoli cells (Levallet et al. 2007a).

PGs are complex molecules composed of sulfated glycosaminoglycans covalently linked to a protein core and are present either in extracellular matrix or associated with cells (Prydz \& Dalen 2000). Cell heparan sulfate PGs (HSPGs) have been involved in numerous processes, such as cell adhesion, cell growth, and cell survival (Bernfield et al. 1999, Tumova et al. 2000). Syndecans are the major HSPGs expressed at the cell surface and the four members of the family (designated syndecans 1-4) identified in vertebrates (Carey 1997) display highly conserved transmembrane and cytoplasmic domains (Tkachenko et al. 2005). Albeit devoid of intrinsic catalytic activity, the presence of an identical COOH-terminal postsynaptic density 95 , disk large, zona occludens-1 (PDZ)-binding motif known to bind at least four PDZ domain-containing proteins (Tkachenko et al. 2005) suggests that syndecans may recruit some signaling complexes at the membrane level.

Use of specific chemical inhibitors of PG synthesis such as sodium chlorate, an inhibitor of the active sulfate donor for sulfotransferases (Baeuerle \& Huttner 1986), and para-nitrophenyl- $\beta$-D-xyloside (PNPX), a competitive inhibitor of endogenous core protein for the elongation of glycosaminoglycan chains (Carey 1991), offers a valuable tool to explore the role of cell PGs in signaling functions. In Sertoli cell cultures, both inhibitors reduce drastically the amount of cell PGs and simultaneous addition of FSH and PNPX or sodium chlorate induces increase in the FSH-stimulated estradiol synthesis (Phamantu et al. 1995, 1999) consequently to a decrease in particulate PDE4 activities (Levallet et al. 2007a). However, due to the half-life (about $12 \mathrm{~h}$ ) of Sertoli cell PGs (Fagnen et al. 1999) which are mainly constituted by transmembrane HSPGs (Brucato et al. 2001), it is likely that early response of Sertoli cell to FSH is probably unaffected by chlorate or PNPX treatment in these experiments. Thus, we have re-evaluated the incidence of alteration of PG synthesis by pretreating Sertoli cell with sodium chlorate for $24 \mathrm{~h}$ before FSH stimulation. This study describes the alteration of deactivation of FSH-stimulated particulate PDE4 activities under chlorate conditions and identified the abolition of FSH-stimulated particulate PP2A-like PP as the main effect induced by the decrease in cell PG content.

\section{Materials and Methods}

\section{Materials}

Ovine FSH (oFSH-20, $4453 \mathrm{IU} / \mathrm{mg}$ ) was kindly provided by the National Institute of Arthritis, Metabolic and Digestive Diseases (Pituitary Hormone Distribution Program, Bethesda, MD, USA). Ultroser SF (steroid-free serum substitute) was purchased from BioSepra (Cergy-Saint-Christophe, France). Okadaiic acid (OA) and calyculin A (CA) were from Calbiochem (Nottingham, UK). $\left[2,8-{ }^{3} \mathrm{H}\right]$ Adenosine $3^{\prime}, 5^{\prime}-$ cyclic phosphate $(1.59 \mathrm{TBq} / \mathrm{mmol})$ was from Amersham Biotech. Cyclic AMP $\left({ }^{3} \mathrm{H}\right)$ assay system and enhanced chemiluminescence (ECL) staining kit were from GE Healthcare Europe (Orsay, France). PDE4D (K-16) and PP2A (C-20) antibodies, blocking peptide, and horse radish peroxidase (HRP)-conjugated secondary antibodies were from Santa Cruz Biotechnology Inc. (Santa Cruz, CA, USA), monoclonal mouse anti-actin (Ab-1) from Calbiochem (Darmstadt, Germany). All others reagents were of analytical grade.

\section{Cell cultures}

All procedures described within were performed in accordance with French legal requirements for animal handling and welfare. After the killing of 10- to 30-day-old SpragueDawley rats (provided by Elevage Janvier, Le Genest Saint-Isle, France), Sertoli cells were isolated from decapsulated testes by sequential enzymatic digestion at $32{ }^{\circ} \mathrm{C}$ (trypsin, then collagenase/dispase plus hyaluronidase) as previously described (Levallet et al. 2007b) and cultured at $32{ }^{\circ} \mathrm{C}$ under $5 \% \mathrm{CO}_{2}$ atmosphere (v/v) for $48 \mathrm{~h}$ in Ham's F12-Dulbecco's modified Eagle's medium (1:1) supplemented with antibiotics (50 $000 \mathrm{UI} / 1$ penicillin, $50 \mathrm{mg} / 1$ streptomycin and $50 \mathrm{mg} / 1$ kanamycin), fungicide $(0 \cdot 25 \mathrm{mg} / 1$ amphotericin B), $2 \cdot 2 \mathrm{~g} / 1$ sodium bicarbonate, and $2 \%$ Ultroser SF (v/v). Seeding Sertoli cell densities and contamination by peritubular and germ cells have been previously described (Levallet et al. 2007b).

On day 3 after plating, residual germ cells were lysed by hypotonic treatment using $20 \mathrm{mM}$ Tris- $\mathrm{HCl}$ buffer ( $\mathrm{pH} 7 \cdot 4$; Galdieri \& Zani 1981). Rat Sertoli cells (10- to 30-day-old) were then cultured for additional period (up to 2 days) in medium devoid of Ultroser. Sertoli cell cultures were routinely assayed for peritubular cell contamination by checking the lack 
of histochemical detection of pericellular alkaline phosphatase and absence of fibronectin expression by RT-PCR as previously described (Levallet et al. 2007a,b). On day 4 after plating, 10- to 30 -day-old rat Sertoli cells were incubated for $24 \mathrm{~h}$ in the presence or absence of $10 \mathrm{mM}$ sodium chlorate. At the end of the incubation, the cell medium was renewed and Sertoli cells were further incubated with $100 \mathrm{ng} / \mathrm{ml} \mathrm{FSH}$ for up to $24 \mathrm{~h}$ and in the presence or absence of CA or OA before being assayed for cAMP-PDE and PP2A activities, total RNA extraction, or immunoblotting experiments.

\section{Extraction of total $R N A$ and RT-PCR analysis}

Total RNA was isolated from Sertoli cell cultures (20-day-old rats) with an acid guanidinium thiocyanate-phenol-chloro form (Chomczynski \& Sacchi 1987). RNA were reversetranscribed into cDNA using Moloney-murine-leukaemiavirus reverse transcriptase and used as templates for PCRs (Levallet et al. 2007a,b). The primers included 5'-TACTCCGAGGGAATCACGAG-3' and 5'-CTCGGATGTGATCCAGTGTG-3' for Pp2a-C $\alpha$ (Accession no. NM_017039), $5^{\prime}$-GGCCCAATGTGTGATCTCTT-3' and 5'-CCATTACAAGCTGGTGAGCA-3' for $P p 2 a-C \beta$ (NM_017040), $5^{\prime}$-ACAGACTACCTCATGAAGAT- $3^{\prime}$ and $5^{\prime}$-AGCCATGCCAAATGTCTCAT- $3^{\prime}$ for $\beta$-actin (V01217). According to the PCR primer set, the following conditions were used: denaturation at $94{ }^{\circ} \mathrm{C}$ for $1 \mathrm{~min}$, annealing at $55^{\circ} \mathrm{C}(\beta$-actin $)$ or $60{ }^{\circ} \mathrm{C}(\mathrm{Pp} 2 \mathrm{a}-\mathrm{C})$ for $45 \mathrm{~s}$, and extension at $72{ }^{\circ} \mathrm{C}$ for $1 \mathrm{~min}$ for 35 and 22 cycles for PP2A and Actin amplification respectively. PCR products were separated by electrophoresis in a $2.5 \%$ agarose gel (w/v) and stained with ethidium bromide. Gels were photographed under u.v. illumination, and densities of the bands were measured using NIH Image J software (National Institute of Health, Bethesda, MD, USA).

\section{Preparation of cell fractions}

Cultured Sertoli cells from 10-, 20-, and 30-day-old rats were washed with cold PBS and recovered by gentle scraping in lysis buffer (20 mM Tris- $\mathrm{HCl} \mathrm{pH} 7 \cdot 2,1 \mathrm{mM}$ EDTA, $250 \mathrm{mM}$ sucrose) supplemented with $0.1 \mathrm{mM}$ phenylmethanesulfonyl fluoride, $2 \mathrm{mM}$ benzamidin, and a mixture of antiproteases (antipain, aprotinin, leupeptin, pepstatin A) at a final concentration of $1 \mu \mathrm{g} / \mathrm{ml}$ and centrifuged at $100000 \mathrm{~g}$ for $1 \mathrm{~h}$ at $4{ }^{\circ} \mathrm{C}$, as previously described (Levallet et al. 2007a,b). The supernatant (soluble fraction) and the pellet (particulate fraction) were then stored at $-20{ }^{\circ} \mathrm{C}$ before the determination of total and rolipramsensitive PDE activities. The purity of each subcellular fraction was checked by assaying both lactate dehydrogenase (soluble activity) and alkaline phosphatase (membrane-associated activities) as has been previously described (Levallet et al. 2007b).

\section{PDE assay}

PDE activities were assayed according to the two-step modified procedure of Thompson \& Appleman (1971).
Protein mixture $(10 \mu \mathrm{g})$ was incubated at $34{ }^{\circ} \mathrm{C}$ for $15 \mathrm{~min}$ in $200 \mu \mathrm{l}$ of reaction buffer $(40 \mathrm{mM}$ Tris- $\mathrm{HCl}(\mathrm{pH} 8 \cdot 1), 1 \mathrm{mM}$ $\mathrm{MgCl}_{2}, 1.25 \mathrm{mM} \beta$-mercapto-ethanol, $\left.0.14 \mathrm{mg} \mathrm{BSA}\right)$ in the presence of $1 \mu \mathrm{M}$ camp $\left(\left[2,8-{ }^{3} \mathrm{H}\right]\right.$-cAMP $(3 \cdot 7 \mathrm{kBq} /$ tube $\left.)\right)$. To identify the cAMP-PDE4 activity, a specific inhibitor, rolipram, was added to the incubation mixture at a final concentration of $10 \mu \mathrm{M}$. The PDE activity measured in the presence of rolipram was subtracted from the total activity to quantify the PDE4 activity.

The reaction was then stopped by the addition of $200 \mu \mathrm{l}$ of stop solution (40 mM Tris- $\mathrm{HCl}$ ( $\mathrm{pH} \mathrm{7 \cdot 5),10} \mathrm{mM} \mathrm{EDTA)}$ followed by heat denaturation at $100{ }^{\circ} \mathrm{C}$ for $1 \mathrm{~min}$. Crotalus atrox snake venom $(50 \mu \mathrm{g})$ was added to each sample and incubated at $34{ }^{\circ} \mathrm{C}$ for $20 \mathrm{~min}$. The reaction products were separated by anion exchange chromatography using a freshly prepared solution of Dowex (Dowex/water/ethanol: 1/1/1: $\mathrm{w} / \mathrm{v} / \mathrm{v}$ ) and an aliquot of supernatant was then counted by liquid scintillation (Levallet et al. 2007a,b).

\section{PP2 $A$ activities}

Total PP2 activities in subcellular fractions of cultured Sertoli cells from 20-day-old rats were determined by serine/threonine phosphatase assay system (Promega) containing a synthesized phosphopeptide, RRA(pT)VA compatible with serine/threonine phosphatases $2 \mathrm{~A}, 2 \mathrm{~B}$, and $2 \mathrm{C}$ but poor substrate for protein phosphatase 1 . Assays were conducted according to the manufacturer's procedure using suitable

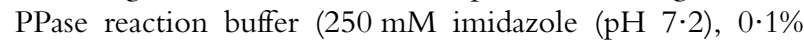
$\beta$-mercaptoethanol (v/v), $1 \mathrm{mM} \mathrm{EGTA,} \mathrm{and} 0.5 \mathrm{mg} / \mathrm{ml}$ BSA) with or without PP2A inhibitor okadaic acid (50 nM). Substrate-released phosphate was quantified by colorimetric method, and PPase activities were expressed first as $\mathrm{pmol} / \mathrm{min}$ per $\mathrm{mg}$ of incubated protein then as $\mathrm{nmol} / \mathrm{min}$ per subcellular fractions.

\section{Western blotting}

Proteins $(25 \mu \mathrm{g})$ of each subcellular fraction obtained from 20-day-old Sertoli cells were boiled for $5 \mathrm{~min}$ and separated by SDS (8\%: (w/v))/PAGE. Proteins were transferred onto nitrocellulose membrane $1 \mathrm{~h}$ at $100 \mathrm{~V}, 4{ }^{\circ} \mathrm{C}$. Western blots were then performed using affinity-purified goat polyclonal antibodies PDE4D (K-16), raised against a peptide mapping near the C-terminus of PDE4D of human origin, and PP2A (C-20) antibody raised against a recombinant protein corresponding to amino acids 1-309 representing full-length protein PP2A catalytic subunit (PP2Ac) of human origin, or monoclonal mouse anti-actin (Ab-1). Immunoreactive bands were detected using the donkey anti-goat IgG-HRP (for PDE4D and PP2A primary antibodies) or goat Anti-mouse IgM, H\&L chain-specific peroxidase conjugate and ECL staining kit. The western blot was scanned on ProXPRESS Proteomic Imaging System (Perkin-Elmer Life Science, Boston, MA, USA) and analyzed with TotalLab Image Analysis software (Nonlinear Dynamics Ltd, Newcastle, UK). 


\section{Statistical analysis}

Differences between treatments were determined by one-way ANOVA followed by Fisher's test using the Sigma Stat software (SPSS Inc., Chicago, IL, USA). Differences were considered significant at $P<0 \cdot 05$.

\section{Results}

Alteration of cell PG by sodium chlorate prolonged the FSH-induced stimulation of particulate PDE4 activities in 20-day-old Sertoli cells

Addition of FSH to Sertoli cell cultures stimulated rolipramsensitive PDE4 activities in both particulate and soluble fractions reaching peak levels (approximately fourfold the initial values) after $6 \mathrm{~h}$ incubation (Fig. 1A). Further duration of incubation led to a progressive decrease in these activities without achieving initial levels particularly for soluble PDE4 activities. In contrast, no stimulation of rolipram-insensitive cAMP-PDE activities
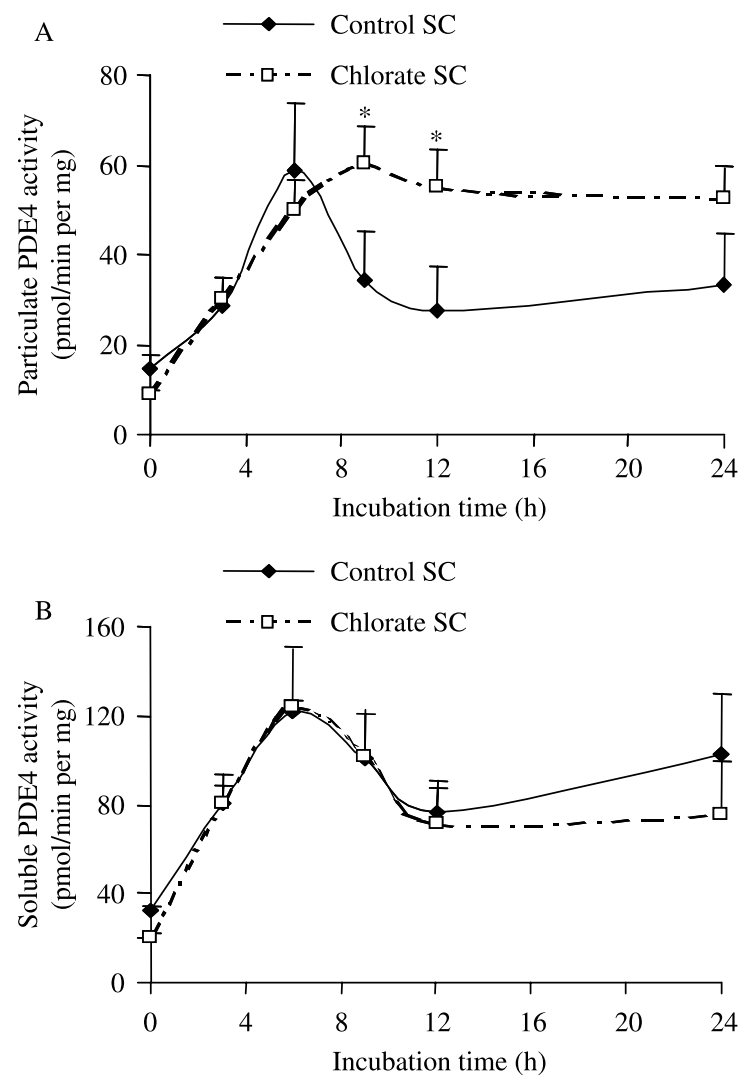

Figure 1 Kinetics of FSH-stimulated particulate (A) and soluble (B) PDE4 activities in untreated and chlorate-treated Sertoli cells (SC) from 20-day-old rats. Sertoli cells were pre-treated (chlorate SC) or not (control SC) with $10 \mathrm{mM}$ sodium chlorate for $24 \mathrm{~h}$ before challenge with FSH $(100 \mathrm{ng} / \mathrm{ml})$ for up to $24 \mathrm{~h}$. PDE4 activities were expressed in pmol cAMP hydrolyzed per min per mg protein. Values are means \pm S.E.M. of three independent experiments. *Significantly different $(P<0 \cdot 05)$ from control SC.
$(84 \cdot 5 \pm 2 \cdot 3$ and $71 \cdot 0 \pm 3 \cdot 5 \%$ of total PDE activities in soluble and particulate fractions respectively) occurred in both subcellular compartments in the presence of gonadotropin (data not shown).

Pre-incubation of cells with sodium chlorate did not alter significantly basal and FSH levels of both particulate and soluble PDE4 activities at least during $6 \mathrm{~h}$ after the onset of the stimulation. However, in chlorate-treated Sertoli cells, the decrease in FSH-stimulated particulate PDE4 activities recorded after $6 \mathrm{~h}$ was totally suppressed (Fig. 1A) whereas the pattern of FSH-stimulated soluble PDE4 activities was unaffected (Fig. 1B) as well as those of rolipram-insensitive PDE activities in both subcellular compartments (data not shown).

A similar effect, although of lesser amplitude, was observed when the alteration of cell PG was induced by pre-incubation for $24 \mathrm{~h}$ in the presence of $1 \mathrm{~mm}$ PNPX, a competitive inhibitor of endogenous core protein for the elongation of glycosaminoglycan chains (data not shown). Moreover, pretreatment of Sertoli cells with $10 \mathrm{mM} \mathrm{NaCl}$ or $10 \mathrm{mM}$ PNPG, and the structural analogues of sodium chlorate and
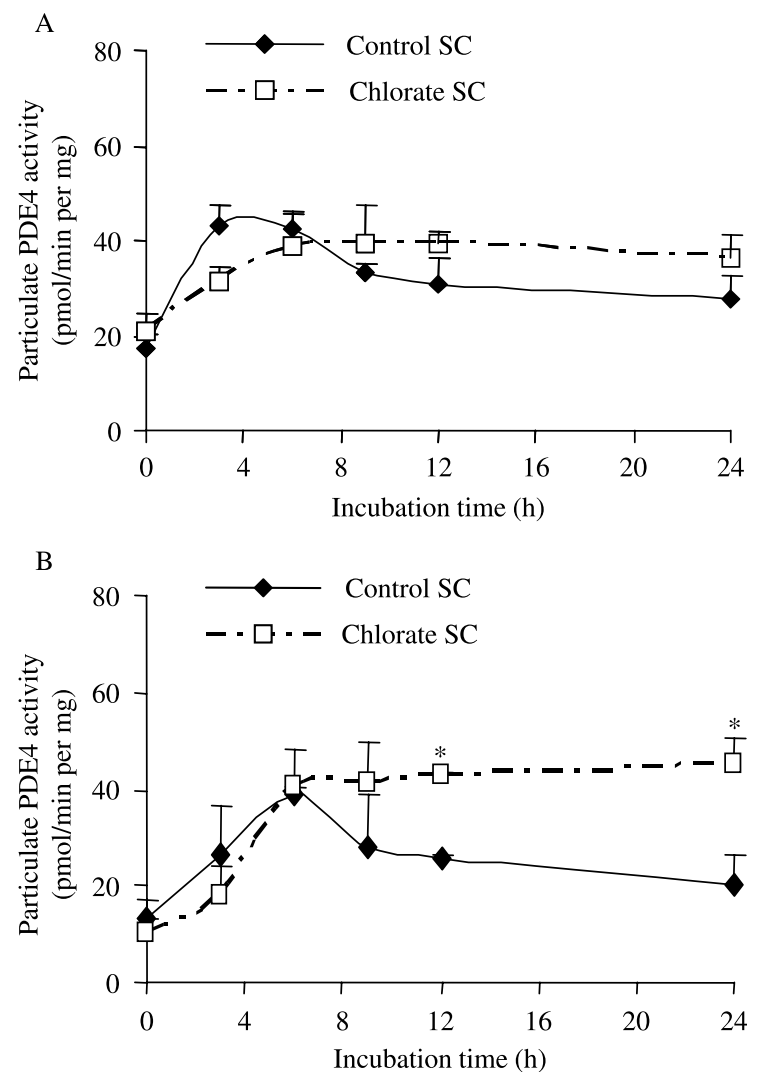

Figure 2 The ability of sodium chlorate to alter time course of FSH-stimulated particulate PDE4 activities in Sertoli cells (SC) is developmentally regulated. Sertoli cells from (A) 10- and (B) 30-dayold rats were pre-treated (chlorate SC, dashed lines) or not (control SC, solid lines) with $10 \mathrm{mM}$ sodium chlorate for $24 \mathrm{~h}$, then further stimulated with FSH $(100 \mathrm{ng} / \mathrm{ml})$ for up to $24 \mathrm{~h}$. PDE4 activities were expressed in pmol cAMP hydrolyzed per min per mg protein. Values are means \pm S.E.M. of three (10 days) and four (30 days) independent experiments. *Significantly different $(P<0 \cdot 05)$ from control SC. 
PNPX respectively, which were ineffective upon cell PG synthesis (Phamantu et al. 1995, 1999), did not modify the kinetic pattern of FSH-stimulated PDE4 activities (data not shown). All these data suggest that sodium chlorate effect was specific and related to its ability to decrease cell PG content.

The ability of sodium chlorate to prolong FSH-induced stimulation of particulate PDE4 in immature rat Sertoli cells was developmentally regulated

To strengthen the hypothesis that alteration of cell PGs were involved in the sustained activation of FSH-stimulated particulate PDE4, we have performed similar experiments with Sertoli cells originating from 10- and 30-day-old rats. Differentiation of Sertoli cells was associated to the loss of their ability to divide around days 15-20 post partum (Clermont \& Perey 1957), a process often associated with the HSPG enrichment of cell membrane in many cell types (Leppa et al. 1992, Kato et al. 1995, Inki \& Jalkanen 1996). Although FSH stimulated particulate PDE4 activities in both proliferating (10 days) and quiescent Sertoli cells (30 days; Fig. 2), sodium chlorate had the ability to prolong FSH stimulation only in 30-day-old Sertoli cells. In both cell types, sodium chlorate did not affect the kinetic pattern of FSH-stimulated PDE4 activities in soluble fraction (data not shown). This set of experiments showed that the ability of sodium chlorate to alter the pattern of PDE4 activation under FSH conditions was developmentally regulated and could be related to higher expression of HSPGs in quiescent Sertoli cells.

\section{Long PDE4D isoforms expression was unaffected by sodium} chlorate treatment in 20-day-old rat Sertoli cells

To investigate whether the distribution and/or protein levels of PDE4D isoforms were altered in sodium chlorate-treated cells, subcellular fractions from untreated and chlorate-treated Sertoli cells challenged with FSH were immunoblotted with antihuman PDE4D antibody which has been demonstrated as suitable for detection of rat PDE4Ds. Our previous results have shown that short PDE4D1-like immunoreactive $75 \mathrm{kDa}$ protein was the main PDE4D present in particulate fraction whereas $90 \mathrm{kDa}$ long PDE4Ds, corresponding to PDE4D3 and PDE4D9 isoforms expressed in Sertoli cells, predominated in soluble fraction (Levallet et al. 2007a). As illustrated in Fig. 3, chlorate pre-treatment of Sertoli cells did not alter the expression pattern of immunoreactive $90 \mathrm{kDa}$ proteins in both subcellular fractions but suppressed the FSH-induced up-regulation of PDE4D1 immunoreactive protein in particulate fraction. The other immunoreactive bands $(68,100$, and $110 \mathrm{kDa})$ present in particulate fraction (Levallet et al. 2007a) did not display significant changes in the same conditions (data not shown). Thus, changes in protein levels of PDE4Ds could not account for the sustained PDE4 activities in chlorate-treated Sertoli cells. All these data suggested that the bell-shaped curve of particulate PDE4 activities under FSH conditions mainly resulted from a series of post-translational modifications of long PDE4D isoforms and that chlorate pre-treatment altered exclusively the later step(s) leading to a decrease in particulate PDE4 activities.

\section{PP2A inhibitors mimicked the sustained stimulation of FSH-induced particulate PDE4 activities recorded in sodium chlorate-treated cells}

Since the activation of long PDE4 isoforms was known to result from PKA-induced phosphorylation of Ser residue (Richter et al. 2005), we have hypothesized that decrease in PDE4 activities could be the result of dephosphorylation process induced by a serine/threonine phosphatase. To determine the role of phosphatase activities and their nature,
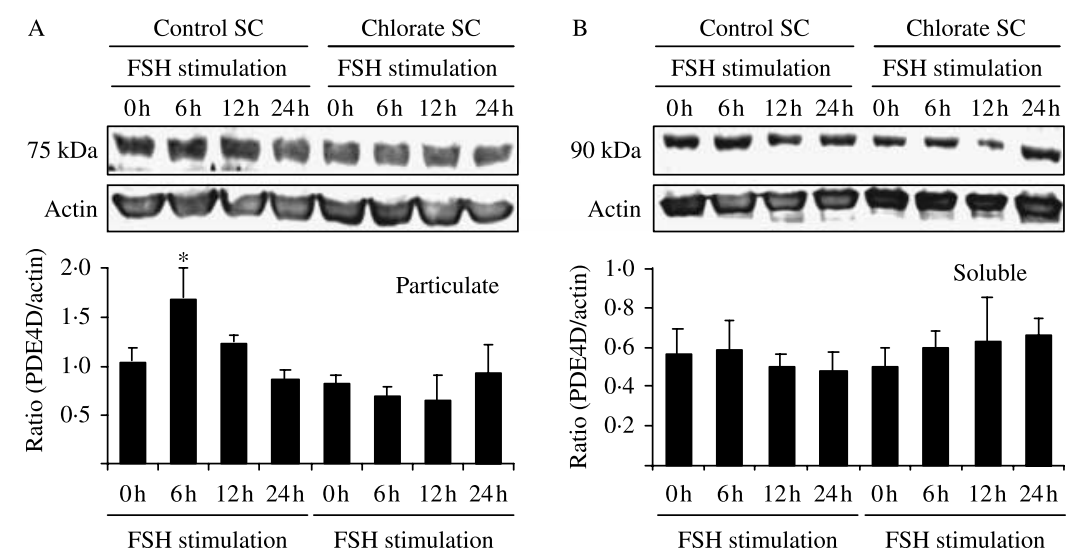

Figure 3 Effects of chlorate pre-treatment on particulate $75 \mathrm{kDa}$ short PDE4D1 and soluble long $90 \mathrm{kDa}$ PDE4Ds protein expressions in Sertoli cells (SC) challenged with FSH. (A) Particulate and (B) soluble fractions were prepared from 20-day-old rat cultured Sertoli cells first pre-treated for $24 \mathrm{~h}$ with (chlorate SC) or without (control SC) $10 \mathrm{mM}$ sodium chlorate, then stimulated with $100 \mathrm{ng} / \mathrm{ml}$ of FSH for the indicated period. Western blot analyses were performed with polyclonal PDE4D antibody against a C-terminal region common to all PDE4D isoforms. Ratios of PDE4D expression to $\beta$-actin loading standard were determined in three separate cultures. Values are mean \pm S.E.M. ${ }^{*}$ Different from $0 \mathrm{~h}$ values at $P<0 \cdot 05$. 
20-day-old rat Sertoli cells were incubated in the presence of $\mathrm{FSH}$ and $30 \mathrm{~min}$ before the peak of PDE4 activities (i.e. $5 \mathrm{~h}$ 30 min after the onset of experiment), phosphatase inhibitors $\mathrm{CA}$ and OA were added to the culture medium.

In untreated Sertoli cells, both CA and OA used at $1 \mathrm{nM}$ prevented the decrease in FSH-stimulated particulate PDE4 activities observed after $6 \mathrm{~h}$ incubation, and sustained these activities at their maximal levels at least for $12 \mathrm{~h}$ (Fig. 4A). Higher concentrations (10 and $100 \mathrm{nM}$ ) of inhibitors gave the same results (data not shown) excepted for 100 nM CA which induced rapid rounding and cell detachment from the substratum, a phenomenon already observed for other cell types (Hosoya et al. 1993). In contrast, the deactivation of FSH-stimulated soluble PDE4 activities was not significantly affected by CA and OA (Fig. 4B), suggesting that mechanisms
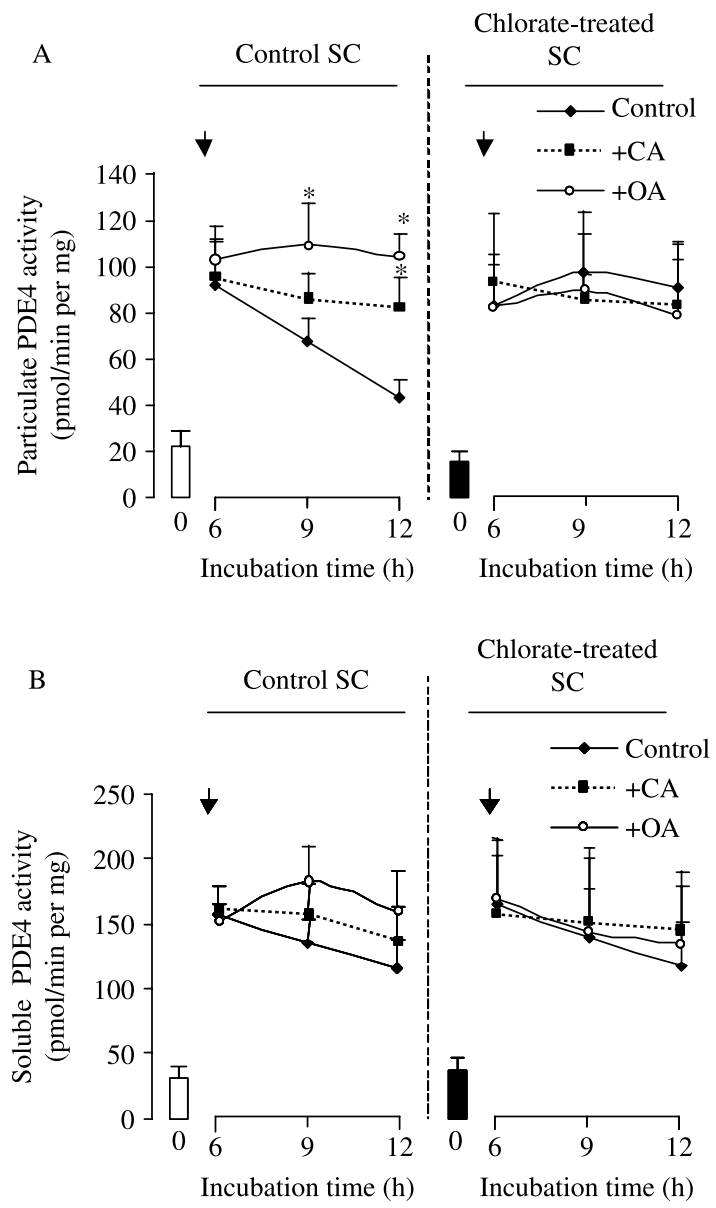

Figure 4 Effects of serine/threonine phosphoprotein phosphatase inhibitors upon kinetics of FSH-stimulated (A) particulate and (B) soluble CAMP-PDE4 activities in untreated and chlorate-treated Sertoli cell (SC) cultures from 20-day-old rat. Arrows indicated the time of addition of $1 \mathrm{nM}$ okadaic acid (open circles) or $1 \mathrm{nM}$ calyculin A (black squares). Values are means \pm s.E.M. of three independent experiments. *Denotes significant effect of phosphatase inhibitor $(P<0 \cdot 05)$. or phosphatases responsible for the deactivation of PDE4 in both subcellular compartments were different.

When Sertoli cells were pre-treated for $24 \mathrm{~h}$ with sodium chlorate, the sustained activation was not further modified by phosphatase inhibitors suggesting that sodium chlorate interfered with particulate PDE4 deactivation by inhibiting serine/threonine phosphatase identified as PP2A on the basis of similar potency of OA and CA to silence particulate PDE4 deactivation.

FSH-induced increase in particulate PP2A activity was abolished in sodium chlorate-treated Sertoli cells

To further investigate the role of PP2A in the deactivation of particulate PDE4 activities, 20-day-old Sertoli cells were stimulated for specific times by the addition of FSH and analyzed for the activity and the distribution of PP2A in soluble and particulate fractions. According to the supplier,

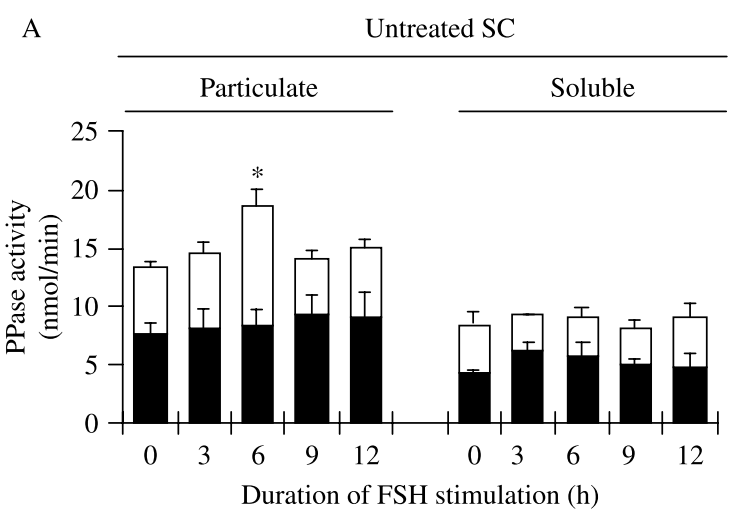

B

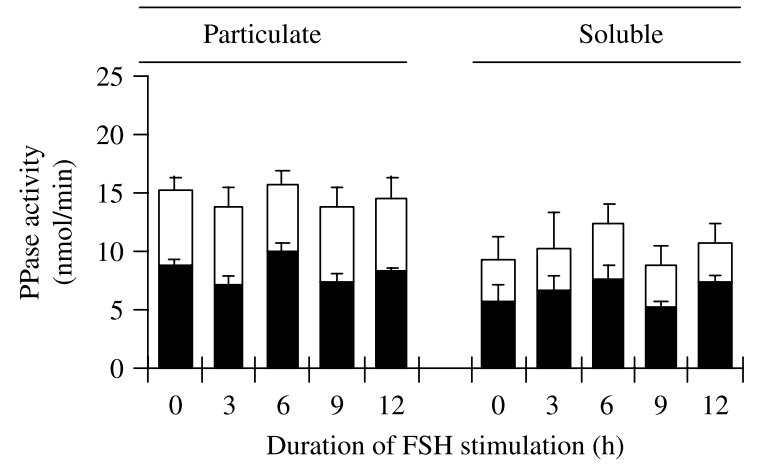

Figure 5 The $\mathrm{FSH}$-induced transient up-regulation of particulate PP2A activities is abolished in chlorate-treated Sertoli cells. Subcellular fractions of 20-day-old Sertoli cell cultures were then assayed for total PP2 activities using serine/threonine phosphatase assay system. Okadaic acid (50 nM)-sensitive PP2A activities (open bars) and other PP2 activities (black bars) were expressed in nmol of phosphate released per min. Values are means \pm S.E.M. of three independent experiments. *Significantly different $(P<0 \cdot 05)$ from unstimulated Sertoli cells. 

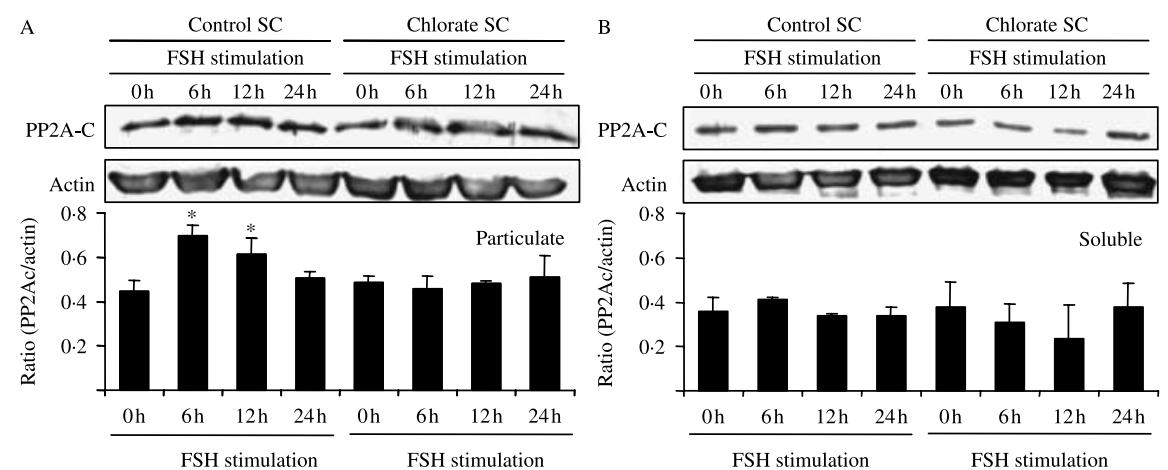

Figure 6 The FSH-induced transient increase in particulate PP2A catalytic subunit expression is abolished in chlorate-treated Sertoli cells. Proteins samples from (A) particulate and (B) soluble fractions were obtained from 20-day-old Sertoli cells (SC) pre-treated (chlorate SC) or not (control SC) with $10 \mathrm{mM}$ sodium chlorate and further stimulated for up to $24 \mathrm{~h}$ with $100 \mathrm{ng} / \mathrm{ml} \mathrm{FSH}$. Western blot analyses were performed with polyclonal anti-PP2A-C antibody densitometric quantifications were performed relative to $\beta$-actin signal. Values are means \pm S.E.M. of three experiments. *Significantly different from control values at $P<0 \cdot 05$.

substrate used in PP2A assay was a poor substrate for PP1 (Donella Deana et al. 1990). Thus, the phosphatase activities determined with this assay were essentially PP2 activities and OA $(50 \mathrm{nM})$-sensitive PP2 activities were considered as PP2A.

In unstimulated Sertoli cells, nearly half of the total PP2 activities was supported by OA-sensitive PP2A activities. Addition of FSH to Sertoli cell cultures induced within $6 \mathrm{~h}$ a $60 \%$ increase in total particulate PP activity which was exclusively supported by OA-sensitive PP2A activity (Fig. 5). The increase in the particulate PP2A activity was transient and the return to initial levels was achieved $3 \mathrm{~h}$ later. The effect of FSH was restricted to the particulate fraction since no modification of soluble PP2A activity was recorded in the soluble fraction. Pre-treatment of Sertoli cells for $24 \mathrm{~h}$ with $10 \mathrm{mM}$ sodium chlorate did not alter endogenous levels or subcellular distribution of PP2 activities but abolished the FSH-induced increase in particulate PP2A activities without apparent changes in soluble activities (Fig. 5).

FSH-induced membrane recruitment of PP2A-C was abrogated in chlorate-treated Sertoli cells

To investigate whether FSH promoted PP2A recruitment in the particulate fraction and whether chlorate pre-treatment altered such a recruitment, we performed a time course immunoblot analysis for the catalytic subunit of PP2A (PP2A-C). As shown in Fig. 6, the $36 \mathrm{kDa}$ immunoreactive PP2A-C was detectable in both particulate and soluble fractions of 20-day-old Sertoli cells. No significant change has been recorded for PP2A-C levels in the soluble fraction of untreated Sertoli cells. However, particulate levels of PP2A-C increased $(+30 \%, P<0.05) 6 \mathrm{~h}$ after FSH treatment, then slowly decreased to return to basal levels at $24 \mathrm{~h}$. The FSH-induced increase in particulate PP2A-C immunoreactivity was totally abolished in chlorate-treated Sertoli cells while the expression of PP2A in soluble fraction was unaffected by chlorate pre-treatment.
FSH-induced increase in particulate PP2A did not result from up-regulation of $\mathrm{Pp} 2 \mathrm{a}-\mathrm{C}$ expression

To assess the involvement of up-regulation of $P p 2 a-C$ gene expressions in the FSH-induced increase in particulate PP2A protein, we sought a possible modification of steady-state mRNA for $P p 2 a-C$. Since mammalian catalytic subunit of PP2A has two isoforms, $\alpha$ and $\beta$, which are $97 \%$ identical and highly conserved (Mayer et al. 1990), we have evaluated the expression of both variants in Sertoli cells. Both isoforms were expressed in cultured Sertoli cells (Fig. 7). Chlorate pre-treatment has no effect on endogenous basal levels of mRNA for both isoforms, and FSH was unable to up-regulate their expression as well in untreated than in chlorate-treated Sertoli cells. Therefore, transcriptional regulation of catalytic subunit did not account for the changes in particulate PP2A immunoreactive expression and activity observed in our experiments.

\section{Discussion}

This report shows that transient and inducible PP2A activity is responsible for the deactivation of FSH-stimulated particulate PDE4 activities in Sertoli cells and that effect is abolished after an alteration of cell PG synthesis. Thus, PKA-mediated phosphorylation of long PDE4 isoforms (Richter et al. 2005) and their PP2A-mediated dephosphorylation appear as the main mechanisms controlling particulate PDE4 activities. The abolition of FSH-induced up-regulation of particulate PDE4D1 immunoreactive expression (Fig. 3A) without concomitant changes in the peak values of PDE4 activities strongly suggests that PDE4D1 plays a minor role in the 6-h peak in cAMP-catabolizing activities triggered by $\mathrm{FSH}$. However, that abolition may explain the accelerated return of PDE4D activities to baseline values recorded in our previous experiments when Sertoli cells were treated simultaneously with FSH and sodium chlorate (Levallet et al. 2007a). 
A
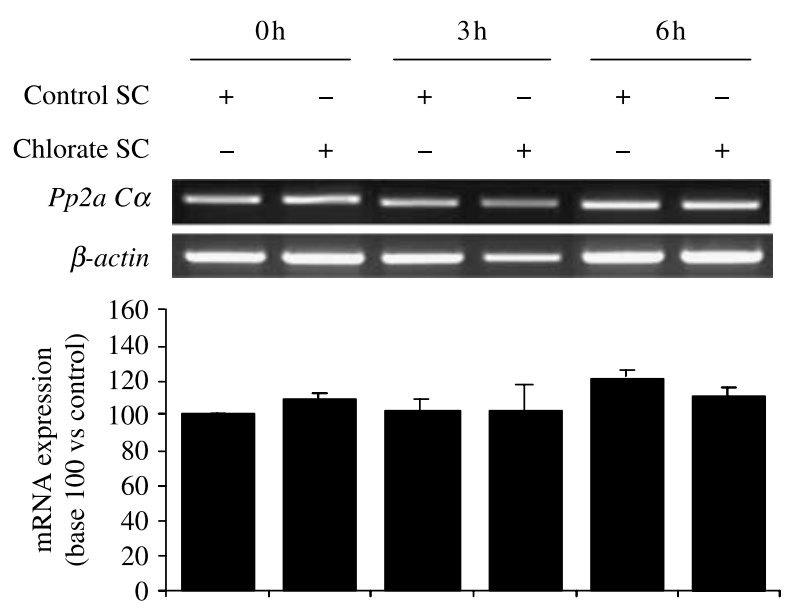

B
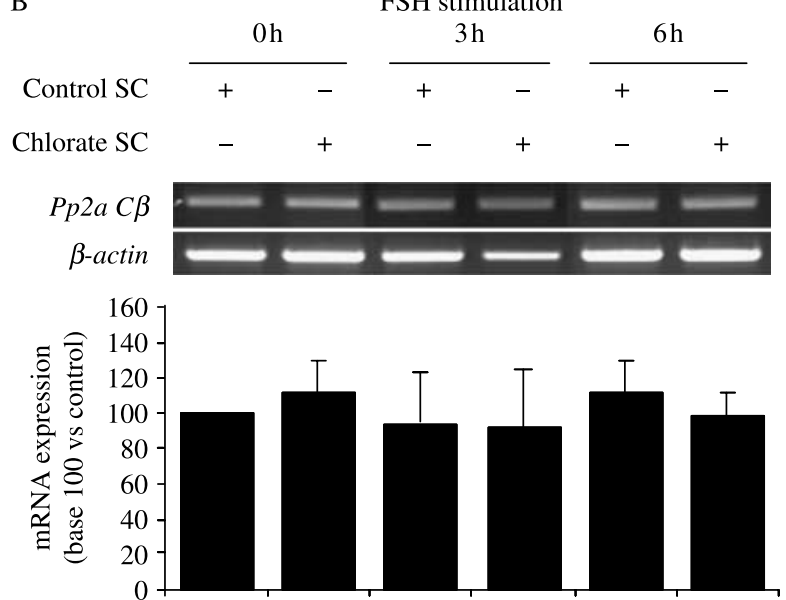

Figure 7 Lack of transcriptional regulation of (A) $P p 2 a-C \alpha$ and (B) $P p 2 a-C \beta$ expression by FSH in untreated and chlorate-treated 20-day-old rat Sertoli cells. Expression was semi-quantified by RT-PCR using specific primers. Densitometric data for each gene expression was normalized to the $\beta$-actin levels before expressed relative to endogenous level in untreated Sertoli cells. Means \pm S.E.M. from three different cultures are illustrated.

The precise mechanisms by which FSH itself limits excessive cAMP catabolism by reversing phosphorylation of particulate PDE4 activities are still unknown. Previous studies have shown that cAMP transiently up- or down-regulates PP2A activity in various cell types (Feschenko et al. 2002, Moon \& Lerner 2003, Pullar et al. 2006), but the regulatory mechanisms controlling PP2A activity are not fully understood. In Sertoli cells, increase in PP2A activities under FSH conditions does not result from transcriptional up-regulation of PP2A-C isoforms, in agreement with the autoregulatory mechanism preventing fluctuation in $\mathrm{PP} 2 \mathrm{~A}-\mathrm{C}$ translation (Baharians \& Schonthal 1998). Evidence suggest that PP2A is mainly, if not exclusively, regulated by post-translational modifications of PP2A-C and regulatory subunits (Longin et al. 2007), association of PP2A-C with regulatory proteins (Strack et al. 2004), and subcellular localization of the PP2A holoenzyme (Strack et al. 1998). However, timing of particulate PP2A activation in Sertoli cells seems exclude any acute post-translational modification of PP2A-C subunit, such as phosphorylation (Janssens \& Goris 2001) and carboxymethylation (Longin et al. 2007) or phosphorylation of regulatory subunit of the holoenzyme (Ahn et al. 2007). A growing body of evidence suggests that a unique combination of regulatory subunits governs the enzymatic activity, substrate specificity, and location of PP2A enzymes (Janssens \& Goris 2001, Strack et al. 2004, Janssens et al. 2005). Kinetics of particulate PP2A activity and protein expression in FSH-treated Sertoli cells suggest that a transcriptional mechanism is involved in the gonadotropininduced up-regulation of particulate PP2A. The identification of the transcriptionally regulated $\mathrm{B}$ subunit involved in the recruitment/activation of particulate PP2A in Sertoli cells could be an interesting challenge for the future. Moreover, the inefficiency of both okadaic acid and calyculin to prevent the decrease in FSH-stimulated soluble PDE4 activities and the lack of FSH-induced up-regulation of soluble PP2A suggest that the mechanisms controlling the deactivation of PDE4 activities are different in particulate and soluble fractions. Whether differences are due to either the presence of structurally different PP2A holoenzymes or the involvement of different phosphatases in particulate and soluble fractions remains to be defined.

Whatever the nature of the mechanism triggered by FSH to target PP2A activities in the particulate fractions, it is clear that cell PGs, and more precisely transmembrane syndecans, play a role in this process. Simultaneous inhibition of both FSH-induced PP2A membrane expression and activation under chlorate conditions may suggest that syndecanmediated anchorage of PP2A to the membrane is a prerequisite for PP2A activation, likely through association with other proteins in scaffolding complexes. Data on the signaling complexes associated with syndecans are limited, and to date only a still unidentified PP activated by fibroblast growth factor (FGF)-2 was found to be associated with the cytoplasmic tail of syndecan-4 through a PDZ adaptor protein (Horowitz et al. 2002). Due to the presence of an identical C-terminal PDZ-binding motif in all syndecans (Tkachenko et al. 2005), it is likely that such association is not restricted to syndecan-4. Moreover, the constitutive binding of regulatory subunits of PKA to the syndecan- 1 cytoplasmic domain (Hayashida et al. 2006) suggests that PP2A and PKA could be closely anchored at the cell membrane, thereby facilitating PKA-mediated activation of particular PP2A holoenzyme recruited by syndecan-1 or another syndecan.

The temporally and spatially regulated expression of syndecans (Salmivirta \& Jalkanen 1995, Tkachenko et al. 2005) suggests that these HSPGs fulfill developmental functions in vivo. Thus, it is noteworthy that cessation of Sertoli cell proliferation around 15 days post partum (Clermont \& Perey 1957), a phenomenon associated in other cell types 
with an increased expression of syndecan-1 (Leppa et al. 1992, Kato et al. 1995, Inki \& Jalkanen 1996), is timely related to the ability of sodium chlorate to abolish particulate PDE4 deactivation. These data suggest that, in contrast with quiescent and differentiated Sertoli cells, PG-mediated particulate activation/recruitment of PP2A by FSH is not fully operational in proliferating Sertoli cells from 10-day-old rats albeit the maximal in situ immunoreactivity of PP2A-A subunit (van den Ham et al. 2003), whose postulated role is to stabilize the PP2A holoenzyme (Chen et al. 2005).

The promotion of interaction between PP2A and transmembrane PGs in non-proliferating Sertoli cells could likely fulfill more than a simple role in the reversal of the activated particulate PDE4D back to its pre-stimulatory, inactive state. Interestingly, the onset of fully operational PG-mediated recruitment/activation of particulate PP2A in response to FSH corresponds to the time of increase in cAMP pathway sensitization toward the gonadotropin (Levallet et al. 2007b). This period of transition from proliferating to differentiated state is also associated with switching of FSH receptor from MAPK3/1 (also known as Erk 1/2) activation to adenylate cyclase activation in Sertoli cells (Crepieux et al. 2001), a process requiring cell adhesion (Crepieux et al. 2002). Similar switching for the $\beta_{2}$-adrenergic receptor has been associated with dephosphorylation of the receptor (Daaka et al. 1997). Hence, syndecans, by their phenotype-dependent expression and their membrane location may fulfill yet unsuspected functions in the control of cellular responses to FSH or other external stimuli by anchoring and compartmentalize PP2A activity. Additional experiments will be required to identify the syndecan involved in these processes, even though the similar basolateral distribution of syndecan-1 (Miettinen et al. 1994) and FSH receptor (Vannier et al. 1996) suggest that syndecan-1 is the most probable candidate.

\section{Acknowledgements}

This study was supported by a fellowship grant to G L from the Ministère de l'Enseignement Supérieur et de la Recherche. The authors declare that there is no conflict of interest that would prejudice the impartiality of this scientific work.

\section{References}

Ahn JH, McAvoy T, Rakhilin SV, Nishi A, Greengard P \& Nairn AC 2007 Protein kinase A activates protein phosphatase $2 \mathrm{~A}$ by phosphorylation of the B56delta subunit. PNAS 104 2979-2984.

Baeuerle PA \& Huttner WB 1986 Chlorate - a potent inhibitor of protein sulfation in intact cells. Biochemical and Biophysical Research Communications $141870-877$.

Baharians Z \& Schonthal AH 1998 Autoregulation of protein phosphatase type 2A expression. Journal of Biological Chemistry 273 19019-19024.

Baillie GS, Scott JD \& Houslay MD 2005 Compartmentalisation of phosphodiesterases and protein kinase A: opposites attract. FEBS Letters 579 3264-3270.
Bender AT \& Beavo JA 2006 Cyclic nucleotide phosphodiesterases: molecular regulation to clinical use. Pharmacological Reviews 58 488-520.

Bernfield M, Gotte M, Park PW, Reizes O, Fitzgerald ML, Lincecum J \& Zako M 1999 Functions of cell surface heparan sulfate proteoglycans. Annual Review of Biochemistry 68 729-777.

Brucato S, Fagnen G, Villers C, Bonnamy PJ, Langris M \& Bocquet J 2001 Biochemical characterization of integral membrane heparan sulfate proteoglycans in Sertoli cells from immature rat testis. Biochimica et Biophysica Acta 1510 474-487.

Carey DJ 1991 Biological functions of proteoglycans: use of specific inhibitors of proteoglycan synthesis. Molecular and Cellular Biochemistry 104 21-28.

Carey DJ 1997 Syndecans: multifunctional cell-surface co-receptors. Biochemical Journal 327 1-16.

Chen W, Arroyo JD, Timmons JC, Possemato R \& Hahn WC 2005 Cancerassociated PP2A Aalpha subunits induce functional haploinsufficiency and tumorigenicity. Cancer Research 65 8183-8192.

Chomczynski P \& Sacchi N 1987 Single-step method of RNA isolation by acid guanidinium thiocyanate-phenol-chloroform extraction. Analytical Biochemistry 162 156-159.

Clermont Y \& Perey B 1957 Quantitative study of the cell population of the seminiferous tubules in immature rats. American Journal of Anatomy $100241-267$.

Conti M \& Beavo J 2007 Biochemistry and physiology of cyclic nucleotide phosphodiesterases: essential components in cyclic nucleotide signaling. Annual Review of Biochemistry 76 481-511.

Crepieux P, Marion S, Martinat N, Fafeur V, Vern YL, Kerboeuf D, Guillou F \& Reiter E 2001 The ERK-dependent signalling is stage-specifically modulated by FSH, during primary Sertoli cell maturation. Oncogene $\mathbf{2 0}$ 4696-4709.

Crepieux P, Martinat N, Marion S, Guillou F \& Reiter E 2002 Cellular adhesion of primary Sertoli cells affects responsiveness of the extracellular signalregulated kinases 1 and 2 to follicle-stimulating hormone but not to epidermal growth factor. Archives of Biochemistry and Biophysics 399 245-250.

Daaka Y, Luttrell LM \& Lefkowitz RJ 1997 Switching of the coupling of the $\beta 2$-adrenergic receptor to different $G$ proteins by protein kinase A. Nature 390 88-91.

Donella Deana A, Mac Gowan CH, Cohen P, Marchiori F, Meyer HE \& Pinna LA 1990 An investigation of the substrate specificity of protein phosphatase $2 \mathrm{C}$ using synthetic peptide substrates; comparison with protein phosphatase 2A. Biochimica et Biophysica Acta 1051 199-202.

Fagnen G, Phamantu NT, Bocquet J \& Bonnamy PJ 1999 Activation of protein kinase $\mathrm{C}$ increases proteoglycan synthesis in immature rat Sertoli cells. Biochimica et Biophysica Acta 1472 250-261.

Feschenko MS, Stevenson E, Nairn AC \& Sweadner KJ 2002 A novel cAMPstimulated pathway in protein phosphatase $2 \mathrm{~A}$ activation. Journal of Pharmacology and Experimental Therapeutics 302 111-118.

Galdieri M \& Zani B 1981 Hormonal induced changes in sertoli cell glycoproteins. Cell Biology International Reports 5111.

van den Ham R, van Dissel-Emiliani FM \& van Pelt AM 2003 Expression of the scaffolding subunit $\mathrm{A}$ of protein phosphatase $2 \mathrm{~A}$ during rat testicular development. Biology of Reproduction 68 1369-1375.

Hayashida K, Johnston DR, Goldberger O \& Park PW 2006 Syndecan-1 expression in epithelial cells is induced by transforming growth factor beta through a PKA-dependent pathway. Journal of Biological Chemistry 281 24365-24374.

Horowitz A, Tkachenko E \& Simons M 2002 Fibroblast growth factorspecific modulation of cellular response by syndecan-4. Journal of Cell Biology 157 715-725.

Hosoya N, Mitsui M, Yazama F, Ishihara H, Ozaki H, Karaki H, Hartshorne DJ \& Mohri H 1993 Changes in the cytoskeletal structure of cultured smooth muscle cells induced by calyculin-A. Journal of Cell Science 105 883-890.

Houslay MD \& Adams DR 2003 PDE4 cAMP phosphodiesterases: modular enzymes that orchestrate signalling cross-talk, desensitization and compartmentalization. Biochemical Journal 370 1-18.

Inki P \& Jalkanen M 1996 The role of syndecan-1 in malignancies. Annals of Medicine 28 63-67.

Janssens V \& Goris J 2001 Protein phosphatase 2A: a highly regulated family of serine/threonine phosphatases implicated in cell growth and signalling. Biochemical Journal 353 417-439. 
Janssens V, Goris J \& Van Hoof C 2005 PP2A: the expected tumor suppressor Current Opinion in Genetics and Development 15 34-41.

Kato M, Saunders S, Nguyen H \& Bernfield M 1995 Loss of cell surface syndecan-1 causes epithelia to transform into anchorage-independent mesenchyme-like cells. Molecular Biology of the Cell 6 559-576.

Leppa S, Mali M, Miettinen HM \& Jalkanen M 1992 Syndecan expression regulates cell morphology and growth of mouse mammary epithelial tumor cells. PNAS 89 932-936.

Levallet G, Levallet J \& Bonnamy PJ 2007a Alterations in proteoglycan synthesis selectively impair FSH-induced particulate cAMP-phosphodiesterase 4 (PDE4) activation in immature rat Sertoli cells. Biochimica et Biophysica Acta 1770 638-648.

Levallet G, Levallet J, Bouraima-Lelong H \& Bonnamy PJ $2007 b$ Expression of the cAMP-phosphodiesterase PDE4D isoforms and age-related changes in follicle-stimulating hormone-stimulated PDE4 activities in immature rat sertoli cells. Biology of Reproduction 76 794-803.

Longin S, Zwaenepoel K, Louis JV, Dilworth S, Goris J \& Janssens V 2007 Selection of protein phosphatase $2 \mathrm{~A}$ regulatory subunits is mediated by the C-terminus of the catalytic subunit. Journal of Biological Chemistry.

Lugnier C 2006 Cyclic nucleotide phosphodiesterase (PDE) superfamily: a new target for the development of specific therapeutic agents. Pharmacology and Therapeutics 109 366-398.

Mayer RE, Khew-Goodall Y, Stone SR \& Hemmings BA 1990 Expression and organization of protein phosphatase $2 \mathrm{~A}$ catalytic subunit genes. Advances in Second Messenger and Phosphoprotein Research 24 236-241.

Miettinen HM, Edwards SN \& Jalkanen M 1994 Analysis of transport and targeting of syndecan-1: effect of cytoplasmic tail deletions. Molecular Biology of the Cell 5 1325-1339.

Millward TA, Zolnierowicz S \& Hemmings BA 1999 Regulation of protein kinase cascades by protein phosphatase 2A. Trends in Biochemical Sciences $\mathbf{2 4}$ 186-191.

Moon EY \& Lerner A 2003 PDE4 inhibitors activate a mitochondrial apoptotic pathway in chronic lymphocytic leukemia cells that is regulated by protein phosphatase 2A. Blood $1014122-4130$.

Morena AR, Boitani C, de Grossi S, Stefanini M \& Conti M 1995 Stage and cellspecific expression of the adenosine $3^{\prime}, 5^{\prime}$ monophosphate-phosphodiesterase genes in the rat seminiferous epithelium. Endocrinology 136 687-695.

Phamantu NT, Bonnamy PJ, Bouakka M \& Bocquet J 1995 Inhibition of proteoglycan synthesis induces an increase in follicle stimulating hormone (FSH)-stimulated estradiol production by immature rat Sertoli cells. Molecular and Cellular Endocrinology 109 37-45.

Phamantu NT, Fagnen G, Godard F, Bocquet J \& Bonnamy PJ 1999 Sodium chlorate induces undersulfation of cellular proteoglycans and increases in FSH-stimulated estradiol production in immature rat Sertoli cells. Journal of Andrology 20 241-250.
Prydz K \& Dalen KT 2000 Synthesis and sorting of proteoglycans. Journal of Cell Science 113 193-205.

Pullar CE, Grahn JC, Liu W \& Isseroff RR 2006 ß2-adrenergic receptor activation delays wound healing. FASEB Journal 20 76-86.

Resjo S, Oknianska A, Zolnierowicz S, Manganiello V \& Degerman E 1999 Phosphorylation and activation of phosphodiesterase type 3B (PDE3B) in adipocytes in response to serine/threonine phosphatase inhibitors: deactivation of PDE3B in vitro by protein phosphatase type 2A. Biochemical Journal 341 839-845.

Richter W, Jin SL \& Conti M 2005 Splice variants of the cyclic nucleotide phosphodiesterase PDE4D are differentially expressed and regulated in rat tissue. Biochemical Journal 388 803-811.

Salmivirta M \& Jalkanen M 1995 Syndecan family of cell surface proteoglycans: developmentally regulated receptors for extracellular effector molecules. Experientia 51 863-872.

Strack S, Zaucha JA, Ebner FF, Colbran RJ \& Wadzinski BE 1998 Brain protein phosphatase $2 \mathrm{~A}$ : developmental regulation and distinct cellular and subcellular localization by B subunits. Journal of Comparative Neurology 392 515-527.

Strack S, Cribbs JT \& Gomez L 2004 Critical role for protein phosphatase 2A heterotrimers in mammalian cell survival. Journal of Biological Chemistry 279 47732-47739.

Thompson WJ \& Appleman MM 1971 Multiple cyclic nucleotide phosphodiesterase activities from rat brain. Biochemistry 10 311-316.

Tkachenko E, Rhodes JM \& Simons M 2005 Syndecans: new kids on the signaling block. Circulation Research 96 488-500.

Tumova S, Woods A \& Couchman JR 2000 Heparan sulfate proteoglycans on the cell surface: versatile coordinators of cellular functions. International Journal of Biochemistry and Cellular Biology 32 269-288.

Vannier B, Loosfelt H, Meduri G, Pichon C \& Milgrom E 1996 Anti-human FSH receptor monoclonal antibodies: immunochemical and immunocytochemical characterization of the receptor. Biochemistry 35 1358-1366.

Walker WH \& Cheng J 2005 FSH and testosterone signaling in Sertoli cells. Reproduction 130 15-28.

Wong W \& Scott JD 2004 AKAP signalling complexes: focal points in space and time. Nature Reviews. Molecular Cell Biology 5 959-970.

Received in final form 21 December 2007

Accepted 7 January 2008

Made available online as an Accepted Preprint

7 January 2008 